\title{
Prognostic impact of programmed death-ligand 1 expression in correlation with human leukocyte antigen class $I$ expression status in stage $I$ adenocarcinoma of the lung
}

\author{
Ayako Hirai, MD, ${ }^{\mathrm{a}}$ Kazue Yoneda, $\mathrm{PhD},{ }^{\mathrm{a}}$ Shohei Shimajiri, $\mathrm{MD}, \mathrm{PhD},{ }^{\mathrm{b}}$ Koji Kuroda, MD, PhD, ${ }^{\mathrm{a}}$ \\ Takeshi Hanagiri, MD, PhD, ${ }^{\mathrm{c}}$ Yoshihisa Fujino, $\mathrm{MD}, \mathrm{MPH}, \mathrm{PhD},{ }^{\mathrm{d}}$ and Fumihiro Tanaka, MD, PhD ${ }^{\mathrm{a}}$
}

\section{ABSTRACT}

Objective: The study objective was to investigate the prognostic impact of programmed death-ligand 1 expression in correlation with human leukocyte antigen class I expression on tumor cells in early-stage adenocarcinoma of the lung, because both programmed death-ligand 1 and human leukocyte antigen class I molecules play important roles in cancer immunity.

Methods: Ninety-four patients with completely resected pathologic stage I lung adenocarcinoma were retrospectively reviewed. Programmed death-ligand 1 expression on tumor cells was evaluated with immunohistochemistry in correlation with several clinicopathologic and molecular features, including human leukocyte antigen class I expression on tumor cells.

Results: Fifteen patients $(16.0 \%)$ had tumor with positive programmed death-ligand 1 expression (percentage of tumor cells expressing programmed death-ligand $1, \geq 5 \%$ ), and the incidence was significantly higher in poorly differentiated tumors. There was no significant correlation between human leukocyte antigen class I expression and programmed death-ligand 1 expression. Programmed death-ligand 1 positivity was a significant factor to predict a poor survival (5-year survival, $66.7 \%$ vs $85.9 \% ; P=.049$ ), which was enhanced in tumors with normal human leukocyte antigen class I expression $(P=.029)$ but was not evident in tumors with reduced human leukocyte antigen class I expression $(P=.552)$.

Conclusions: The prognostic impact of programmed death-ligand 1 expression on tumor cells in early-stage lung adenocarcinoma may be distinct according to concurrent human leukocyte antigen class I expression. (J Thorac Cardiovasc Surg 2018;155:382-92)

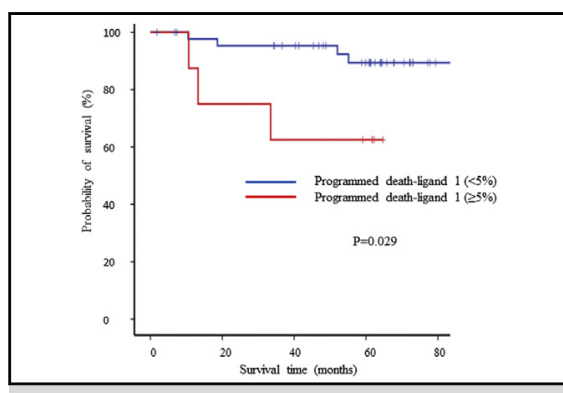

Survival curves according to PD-L1 status in patients with HLA class I expression ( $\geq 80 \%$ ).

\section{Central Message}

The prognostic impact of PD-L1 expression on tumor cells in lung adenocarcinoma was distinct according to concurrent HLA class I expression status.

\section{Perspective}

The prognostic impact of PD-L1 expression on tumor cells was distinct according to HLA class I expression status in pathologic stage I adenocarcinoma of the lung. Tumor cells with reduced HLA class I expression may evade immune attack to survive regardless of PD-L1 status. In contrast, tumor cells with normal HLA class I expression may evade immune attack when they express PD-L1.

See Editorial Commentary page 393.

See Editorial page 363 .
From the Second Departments of a Surgery (Chest Surgery), ${ }^{b}$ Pathology and Cell Biology, and ${ }^{\mathrm{d}}$ Department of Preventive Medicine and Community Health, University of Occupational and Environmental Health; and ${ }^{\mathrm{c}}$ Department of Thoracic Surgery, Shin-Kokura Hospital, Kitakyushu, Japan.

This study was supported in part by the Japan Society for the Promotion of Science: Grants-in-Aid for Scientific Research Grant Numbers 26861131 and 16H01747.

Received for publication Jan 27, 2017; revisions received May 24, 2017; accepted for publication May 31, 2017; available ahead of print July 12, 2017.

Address for reprints: Kazue Yoneda, $\mathrm{PhD}$, Second Department of Surgery, University of Occupational and Environmental Health, 1-1 Iseigaoka, Yahatanishi-ku, Kitakyushu 807-8555, Japan (E-mail: yoneda@med.uoeh-u.ac.jp).

$0022-5223 / \$ 36.00$

Copyright (c) 2017 by The American Association for Thoracic Surgery

http://dx.doi.org/10.1016/j.jtcvs.2017.05.106
Non-small cell lung cancer (NSCLC) accounts for $85 \%$ of lung cancer, which is the leading cause of cancer-related deaths worldwide. ${ }^{1}$ For patients with early-stage NSCLC, surgery is the optimal treatment for cure. ${ }^{2}$ However, the

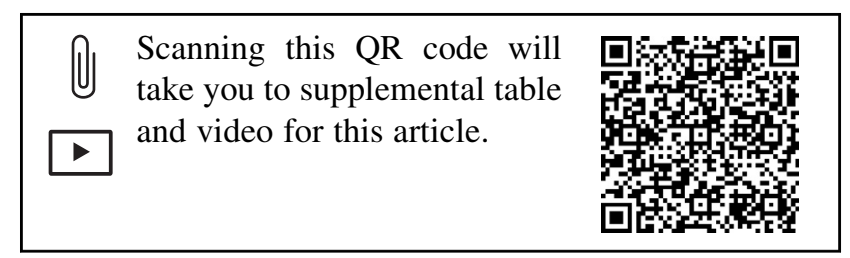




\section{Abbreviations and Acronyms \\ $\mathrm{CI}=$ confidence interval \\ $\mathrm{CTL}=$ cytotoxic $\mathrm{T}$ cell \\ HLA = human leukocyte antigen \\ HR = hazard ratio \\ IHC = immunohistochemistry \\ NSCLC $=$ non-small cell lung cancer \\ OS = overall survival \\ PD-1 = programmed-cell death 1 \\ PD-L1 = programmed death-ligand 1}

postoperative prognosis remains poor, and current adjuvant chemotherapy provides only a modest survival benefit. ${ }^{3,4}$ To improve the prognosis, it is important to establish novel biomarkers to predict prognosis and response to adjuvant chemotherapy. ${ }^{4}$

The programmed-cell death 1 (PD-1) and its ligand (PD-L1) are emerging therapeutic targets in a variety of malignant tumors, including NSCLC. Tumor cells that express PD-L1 may survive immune regulation by binding to PD-1 on cytotoxic T cells (CTLs) and thereby downregulating CTL function, which otherwise would have attacked and killed the tumor cells. ${ }^{5}$ Accordingly, blockade of the PD1/PD-L1 axis may lead to killing tumor cells by restoring cancer immunity, and several antibodies against PD-1 or PD-L1 have achieved promising anti-tumor activity for advanced NSCLC..$^{6-10}$ More important, PD-L1 expression status on tumor cells has been established as a useful biomarker to predict anti-tumor activity of these therapeutic agents. $^{6-9}$

In contrast, the prognostic impact of PD-L1 expression status in early-stage NSCLC remains unclear, partly because of heterogeneity in the patient population (eg, heterogeneous stage and histology) included in each study. ${ }^{11}$ In addition, its prognostic impact may be affected by the status of other biological factors involved in cancer immunity, such as human leukocyte antigen (HLA) class I molecules that play critical roles in an earlier phase for recognition of tumor cells by CTLs. ${ }^{12-14}$ Accordingly, tumor cells with reduced HLA class I molecules may evade immune attack to survive regardless of PD-L1 expression status, which can be associated with a poor prognosis. In contrast, tumor cells with normal HLA class I expression may be recognized and killed by CTLs without PD-L1 expression, and may evade immune attack only when they express PD-L1. However, only a few clinical studies, 1 on cholangiocarcinoma ${ }^{15}$ and 1 on hepatocellular carcinoma, ${ }^{16}$ have assessed the prognostic impact of PD-L1 expression status in combination with HLA class I status. To assess the prognostic impact of PD-L1 expression status in correlation with HLA class I expression status in NSCLC, we conducted a retrospective study in a homogenous patient population with completely resected pathologic (p-) stage I lung adenocarcinoma.

\section{PATIENTS AND METHODS \\ Patients}

Patients with p-stage I lung adenocarcinoma who received complete resection at our institute (Second Department of Surgery [Chest Surgery], University of Occupational and Environmental Health, Japan) from January 2003 to December 2006 without induction therapy before surgery were retrospectively reviewed. All patients received lung resection through minimally invasive thoracotomy. Systemic nodal dissection was principally performed, but was actually performed in 83 patients. Nodal sampling was performed in 8 patients (3 aged $\geq 80$ years, 3 with pulmonary comorbidities, and 2 with cardiovascular comorbidities). No nodal sampling was performed in 3 patients ( 2 patients with pulmonary comorbidities and 1 patient with immunosuppressive treatment for rheumatoid arthritis). In 5 patients who were not fit for lobectomy, limited surgery was performed as follows: segmentectomy in 2 patients ( 1 aged $\geq 80$ years, 1 with severe chronic obstructive pulmonary disease) and wedge resection in 3 patients ( 2 with cardiovascular comorbidities and 1 with idiopathic pulmonary fibrosis) (Table 1).

Patients who did not provide written informed consent for this study were excluded. Patients were ineligible if adequate primary tumor samples for immunohistochemistry (IHC) were not available, and a total of 94 patients were finally included in the study (Figure 1). Whole-body computed tomography, brain magnetic resonance imaging, and bone scan were performed preoperatively. P-stage was determined according to the TNM classification (Union for International Cancer Control TNM staging system, 7th edition). Patients with p-stage IB disease who were fit for adjuvant chemotherapy were encouraged to participate in clinical trials, and 10 patients actually received adjuvant chemotherapy (Table 1). The institutional review board of the University of Occupational and Environmental Health, Japan, approved the present study.

\section{Follow-up Protocol}

For each patient, a routine follow-up was performed at the outpatient clinic as follows: chest roentgenography every 3 months, as well as chest computed tomography, brain magnetic resonance imaging, and bone scan every 6 months for the first 3 years after surgery; all examinations were performed annually thereafter. Additional examinations were performed when any symptoms or signs of recurrence were detected.

The overall survival (OS) was estimated from the date of surgery to death of any cause or the date of the last follow-up. Patients who were not confirmed dead were censored on the date of the last follow-up. A telephone follow-up would be made if the patient did not come to our clinic for a routine follow-up.

\section{Immunohistochemistry}

Serial $4-\mu \mathrm{m}$ sections were cut from each formalin-fixed and paraffin-embedded primary tumor specimen, and received hematoxylineosin staining and IHC staining as described previously. ${ }^{16}$ Sections were heated in $1 \mathrm{mmol} / \mathrm{L}$ ethylenediaminetetraacetic acid $(\mathrm{pH} 8.0)$ at $98^{\circ} \mathrm{C}$ for 15 minutes for antigen retrieval and incubated in 3\% hydrogen peroxide for 10 minutes to inactivate endogenous peroxidase. After blocking with Protein Block Serum-Free (Agilent Technologies, Carpinteria, Calif) for 30 minutes, sections were incubated with rabbit anti-PD-L1 monoclonal antibody (clone E1L3N, Cell Signaling Technology Japan, Tokyo, Japan) diluted at 1:200 for 1 hour at room temperature. Sections were then washed and incubated with SignalStain Boost IHC Detection Reagent HRP Rabbit (Cell Signaling Technology Japan) for 30 minutes. Thereafter, they were visualized with $\mathrm{DAB}+$ Liquid (Agilent Technologies) and counterstained with hematoxylin. 
TABLE 1. Patient characteristics

\begin{tabular}{|c|c|c|c|c|c|c|c|c|c|c|c|c|}
\hline \multirow[b]{2}{*}{ Variables } & \multicolumn{9}{|c|}{ PD-L1 expression } & \multicolumn{3}{|c|}{ HLA class I expression } \\
\hline & $\geq 1 \%$ & $<\mathbf{1} \%$ & $P$ & $\geq \mathbf{5} \%$ & $<5 \%$ & $P$ & $\geq \mathbf{5 0} \%$ & $<\mathbf{5 0} \%$ & $P$ & Normal & Reduced & $P$ \\
\hline $\begin{array}{l}\text { Age, median } \\
\quad(\text { range, y) }\end{array}$ & $75.5(57-85)$ & $71.8(40-88)$ & .1507 & $75.0(58-85)$ & $71.3(40-88)$ & .3547 & $5.0(62-85)$ & $71.5(40-88)$ & .2637 & $72.4(40-85)$ & $69.5(45-88)$ & .738 \\
\hline \multicolumn{13}{|l|}{ Sex } \\
\hline Male $(\mathrm{n}=53)$ & $15(71.4)$ & $38(52.1)$ & .139 & $12(80.0)$ & $41(51.9)$ & .051 & $4(80.0)$ & $49(55.1)$ & .382 & $30(55.6)$ & $23(57.5)$ & 1.000 \\
\hline Female $(n=41)$ & $6(28.6)$ & $35(47.9)$ & & $3(20.0)$ & $38(48.1)$ & & $1(20.0)$ & $40(44.9)$ & & $24(44.4)$ & $17(42.5)$ & \\
\hline \multicolumn{13}{|l|}{ Smoking status } \\
\hline $\begin{array}{l}\text { Former or current } \\
\quad(\mathrm{n}=56)\end{array}$ & $16(76.2)$ & $40(54.8)$ & .129 & $12(80.0)$ & $44(55.7)$ & .093 & $4(80.0)$ & $52(58.4)$ & .645 & $30(55.6)$ & $26(65.0)$ & .400 \\
\hline Never $(\mathrm{n}=38)$ & $5(23.8)$ & $33(45.2)$ & & $3(20.0)$ & $35(44.3)$ & & $1(20.0)$ & 37 (41.6) & & $24(44.4)$ & $14(35.0)$ & \\
\hline $\begin{array}{l}\text { Brinkman Index, } \\
\text { median (pack-y) }\end{array}$ & 40 & 7.5 & .064 & 45 & 10 & .059 & 45 & 15 & .497 & 3.8 & 25 & .264 \\
\hline \multicolumn{13}{|l|}{ Comorbidities, combined } \\
\hline Pulmonary $(\mathrm{n}=26)$ & $10(47.6)$ & $16(21.9)$ & .028 & $6(40.0)$ & $20(25.3)$ & .344 & $2(40.0)$ & $24(27.0)$ & .614 & $17(31.5)$ & $9(22.5)$ & .362 \\
\hline $\begin{array}{l}\text { Cardiovascular } \\
\quad(\mathrm{n}=23)\end{array}$ & $8(38.1)$ & $15(20.5)$ & .148 & $4(26.7)$ & $19(24.1)$ & 1.000 & $2(40.0)$ & $21(23.6)$ & .593 & $15(27.8)$ & $8(20.0)$ & .470 \\
\hline Others $(\mathrm{n}=9)$ & $0(0)$ & $9(12.3)$ & .200 & $0(0)$ & $9(11.4)$ & .346 & $0(0)$ & $9(10.1)$ & 1.000 & $5(9.3)$ & $4(10.0)$ & 1.000 \\
\hline \multicolumn{13}{|l|}{ Cell differentiation } \\
\hline Well $(n=47)$ & $8(42.1)$ & $39(62.9)$ & $<.001$ & $6(46.2)$ & $41(60.3)$ & $<.001$ & $1(25.0)$ & $46(59.7)$ & $<.001$ & $27(60.0)$ & $20(55.6)$ & .757 \\
\hline Moderate $(n=29)$ & $6(31.6)$ & $23(37.1)$ & & $2(15.4)$ & $27(39.7)$ & & $0(0)$ & $29(37.7)$ & & $16(35.6)$ & $13(36.1)$ & \\
\hline Poorly $(\mathrm{n}=5)$ & $5(26.3)$ & $0(0)$ & & $5(38.5)$ & $0(0)$ & & $3(75.0)$ & $2(2.6)$ & & $2(4.4)$ & $3(8.3)$ & \\
\hline \multicolumn{13}{|l|}{$\begin{array}{c}E G F R \text { mutation (del } \\
19 \text { or L858R) }\end{array}$} \\
\hline Mutated $(\mathrm{n}=32)$ & $3(14.3)$ & $29(39.7)$ & .037 & $2(13.3)$ & $30(38.0)$ & .079 & $0(0)$ & $32(36.0)$ & .162 & $18(33.3)$ & $14(35.0)$ & 1.000 \\
\hline Wild-type $(\mathrm{n}=62)$ & $18(85.7)$ & $44(60.3)$ & & $13(86.7)$ & $49(62.0)$ & & $5(100)$ & $57(64.0)$ & & $36(66.7)$ & $26(65.0)$ & \\
\hline \multicolumn{13}{|l|}{ HLA class I expression } \\
\hline Reduced $(\mathrm{n}=40)$ & $8(38.1)$ & $32(43.8)$ & .803 & $7(46.7)$ & $33(41.8)$ & .780 & $1(20.0)$ & $39(43.8)$ & .390 & & & \\
\hline Normal $(\mathrm{n}=54)$ & $13(61.9)$ & $41(56.2)$ & & $8(53.3)$ & $46(58.2)$ & & $4(80.0)$ & $50(56.2)$ & & & & \\
\hline \multicolumn{13}{|l|}{ Surgery type } \\
\hline $\begin{array}{l}\text { Wedge or } \\
\text { segmentectomy } \\
(\mathrm{n}=5)\end{array}$ & $0(0)$ & $5(6.8)$ & .584 & $0(0)$ & $5(6.3)$ & 1.000 & $0(0)$ & $5(5.6)$ & 1.000 & $2(3.7)$ & $3(7.5)$ & .648 \\
\hline $\begin{array}{l}\text { Lobectomy or } \\
\text { pneumonectomy } \\
(\mathrm{n}=89)\end{array}$ & $21(100)$ & $68(93.2)$ & & $15(100)$ & 74 (93.7) & & $5(100)$ & $84(94.4)$ & & $52(96.3)$ & $37(92.5)$ & \\
\hline $\begin{array}{l}\text { No. of nodes } \\
\text { dissected, median }\end{array}$ & 22.0 & 22.0 & .958 & 21.0 & 22.1 & .838 & 21.0 & 21.7 & .844 & 22.5 & 19.5 & .452 \\
\hline \multicolumn{13}{|l|}{ Pathologic stage } \\
\hline IA $(n=67)$ & $13(61.9)$ & $54(74.0)$ & .288 & $9(60.0)$ & $58(73.4)$ & .353 & $1(20.0)$ & $66(74.2)$ & .023 & $40(74.1)$ & $27(67.5)$ & .499 \\
\hline $\mathrm{IB}(\mathrm{n}=27)$ & $8(38.1)$ & $19(26.0)$ & & $6(40.0)$ & $21(26.6)$ & & $4(80.0)$ & $23(25.8)$ & & $14(25.9)$ & $13(32.5)$ & \\
\hline $\begin{array}{l}\text { Adjuvant } \\
\text { chemotherapy, } \\
\text { performed } \\
(\mathrm{n}=10)\end{array}$ & $4(19.0)$ & $6(8.2)$ & .223 & $2(13.3)$ & $8(10.1)$ & .659 & $1(20.0)$ & $9(10.1)$ & .438 & $3(7.5)$ & $7(13.0)$ & .509 \\
\hline
\end{tabular}

Data represented as absolute counts (\%) or median (range). PD-L1, Programmed death-ligand 1; HLA, human leukocyte antigen; EGFR, epidermal growth factor receptor.

Each slide was independently examined by 2 of the investigators (A.H. and S.S.) without any knowledge of the clinical data. When a discrepancy was found between the 2 investigators, a consensus was reached via their simultaneous examination using a double-headed microscope. Each tumor cell was judged as positive staining for PD-L1 when the membrane was stained at any intensity. Each patient was classified into "negative" PD-L1 or "positive" PD-L1 according to the percentage of PD-L1-positive tumor cells; 3 exploratory cutoff values $(1 \%, 5 \%, 50 \%)$, which were identified in previous clinical studies, ${ }^{6-11}$ were used and analyzed.

HLA class I expression had been evaluated in a previous study with IHC using an anti-HLA class I antibody (EMR8-5, Cosmo Bio, Tokyo, Japan). ${ }^{17}$ According to the percentage of HLA class I-positive tumor cells (HLA + tumor cells), each patient had been classified as "normal" expression (HLA+ tumor cells, $\geq 80 \%$ ) or "reduced" expression $(\text { HLA+ tumor cells, }<80 \%)^{17}$ 


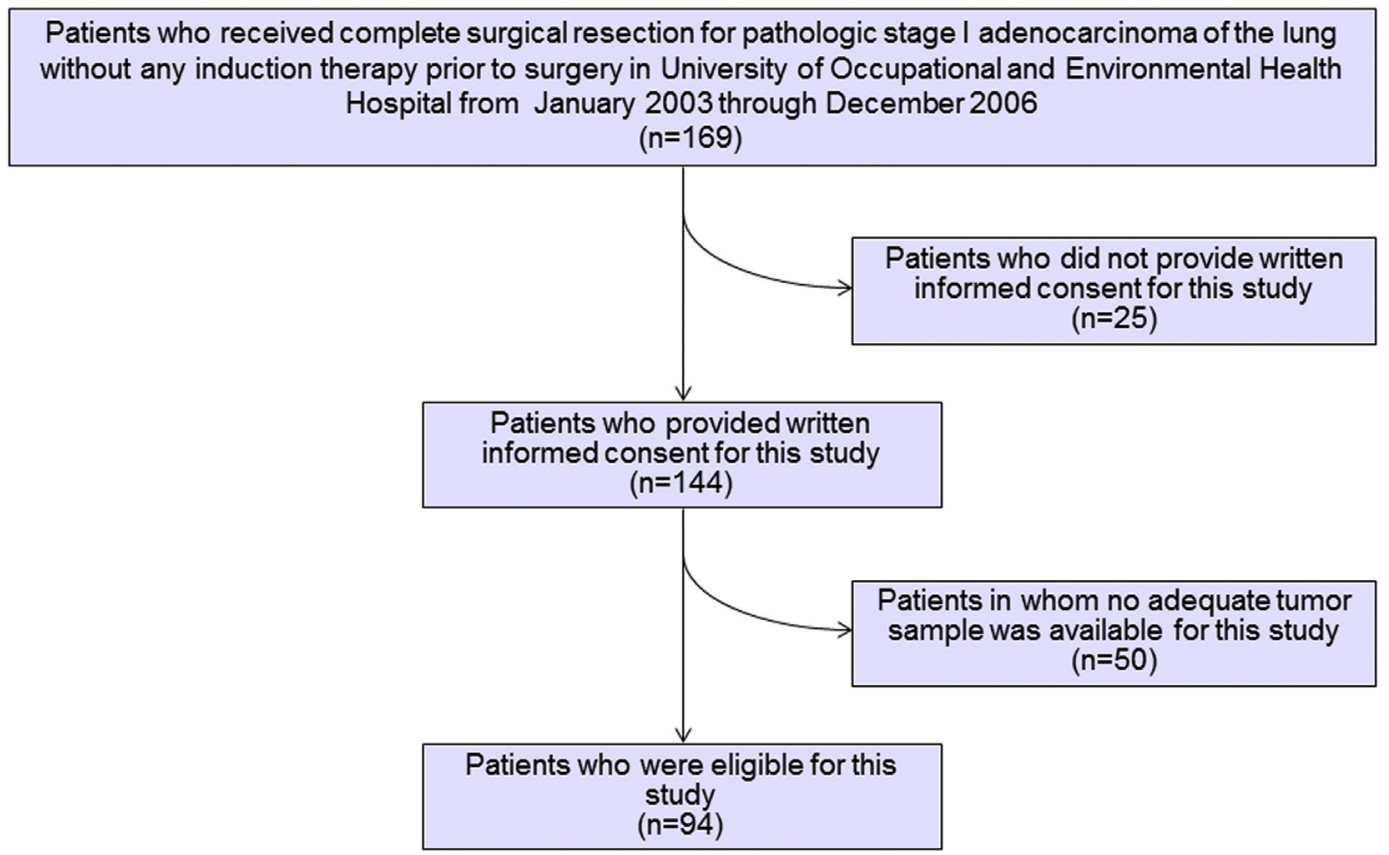

FIGURE 1. CONSORT diagram of the study.

\section{Statistical Analyses}

The proportions of categoric data were compared by the chi-square test. Continuous data were compared using a nonparametric test (Mann-Whitney $U$ test).

The Kaplan-Meier method was used to estimate the probability of survival, and survival differences were analyzed by the log-rank test. To identify independent prognostic factors, univariable and multivariable analyses using Cox proportional hazards regression models were performed. Variables with a $P$ value less than .1 in the first univariable analyses were included in multivariable models. The hazard ratio (HR) and $95 \%$ confidence interval (CI) were calculated for each variable.

All statistical analyses were performed with EZR software (Saitama Medical Center, Jichi Medical University, Saitama, Japan), which is a modified version of $\mathrm{R}$ (The $\mathrm{R}$ Foundation for Statistical Computing, Vienna, Austria). ${ }^{17}$

\section{RESULTS}

\section{Programmed Death-Ligand 1 Expression in Lung Adenocarcinoma}

PD-L1 expression was positive in 21 patients $(22.3 \%)$ at the cutoff value of $1 \%, 15$ patients $(16.0 \%)$ at the cutoff value of $5 \%$, and 5 patients $(5.3 \%)$ at the cutoff value of $50 \%$.

Positive PD-L1 expression was more frequently seen in poorly differentiated tumors than in well-differentiated tumors. In addition, positive PD-L1 expression seemed to be less frequent among epidermal growth factor receptor-mutated tumors. No significant correlation between PD-L1 expression status at any cutoff value and smoking status was observed (Table 1).

In this cohort, HLA class I expression was "normal" in 54 patients $(57 \%)$ and "reduced" in 40 patients $(43 \%)$.
No significant correlation was observed between HLA class I expression and PD-L1 expression, and no other patient characteristic was observed (Table 1).

\section{Programmed Death-Ligand 1 Expression and Survival}

The median follow-up period for all patients was 61.2 months. The 5-year OS of PD-L1-positive and PD-L1-negative patients using each cutoff value was $76.2 \%$ and $85.1 \%$ (cutoff, $1 \% ; P=.249$ ) (Figure 2, $A$ ), $66.7 \%$ and $85.9 \%$ (cutoff, $5 \% ; P=.049$ ) (Figure 2, $B$ ), and $40.0 \%$ and $85.3 \%$ (cutoff, $50 \% ; P=.005$ ) (Figure 2,C), respectively, showing that positive PD-L1 expression with higher cutoff values was associated with a poor prognosis.

There was no significant difference in OS according to HLA class I status (5-year survival, 79.1\% in "reduced" patients vs $85.3 \%$ in "normal" patients; $P=.378$ ). An additional exploratory analysis in which the percentage of tumor cells expressing HLA class I was used as a continuous variable also revealed no significant correlation between HLA class I expression status and OS (HR, 0.999; 95\% CI, 0981-1.017; $P=.891)$.

When analyzed by PD-L1 expression status with stratification by HLA class I status, a significantly poor prognosis in PD-L1-positive patients (cutoff value, $5 \%$ or $50 \%$ ) was documented only when HLA class I expression was "normal" (Video 1). The 5-year survivals of PD-L1negative and positive patients were $88.6 \%$ versus $76.9 \%$ at the cutoff value of $1 \%(P=.186) ; 89.4 \%$ versus $62.5 \%$ at the cutoff value of $5 \%(P=.029)$ (Figure $3, A)$; and 

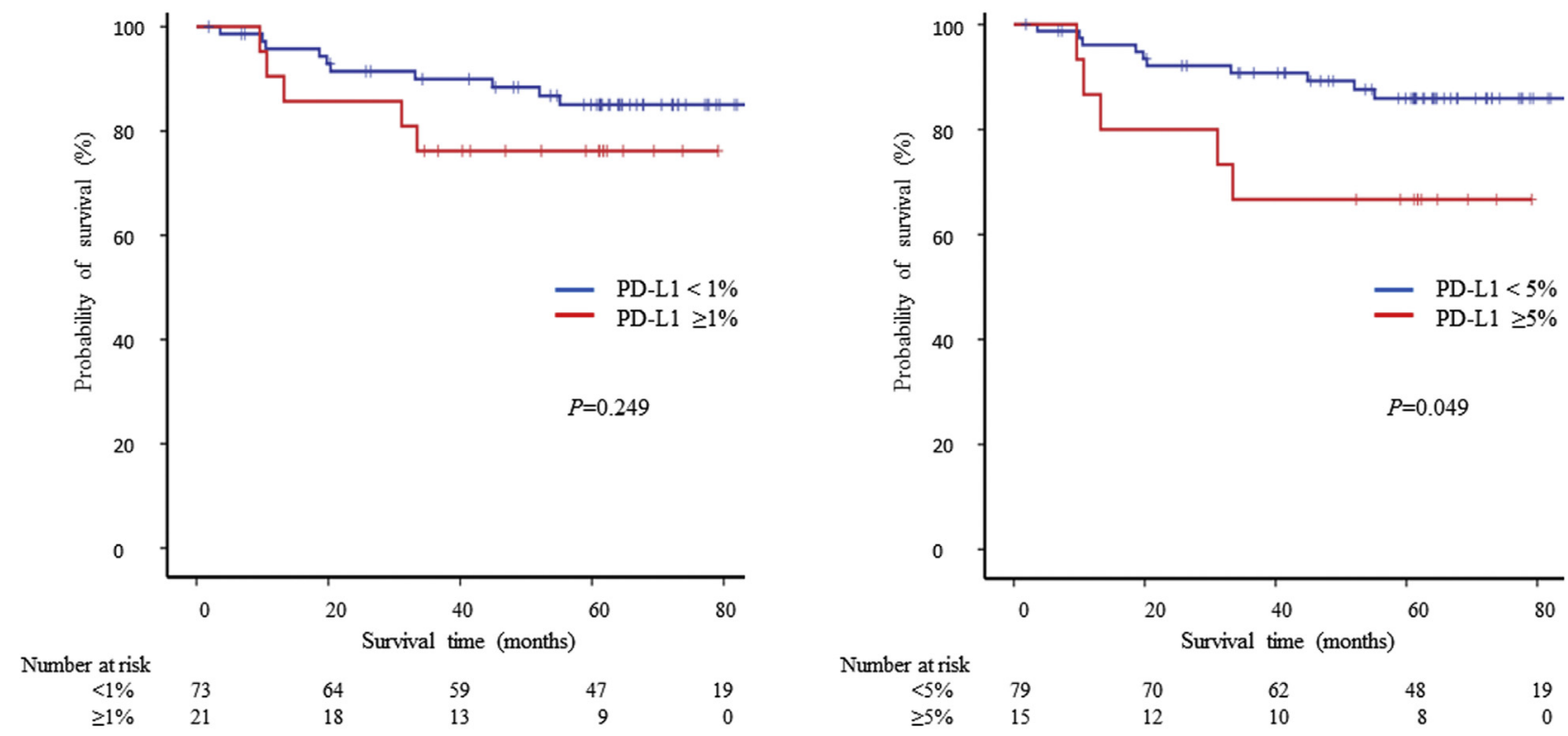

Overall survival at $3 \& 5$ years after surgery

$\begin{array}{lll}<1 \% & 89.9 \%, 95 \% \mathrm{CI}(86.3-93.5) & 85.1 \%, 95 \% \mathrm{CI}(80.7-89.5) \\ \geq 1 \% & 76.2 \%, 95 \% \mathrm{CI}(66.9-85.5) & 76.2 \%, 95 \% \mathrm{CI}(66.9-85.5)\end{array}$

Overall survival at $3 \& 5$ years after surgery

$\begin{array}{lll}<5 \% & 90.7 \%, 95 \% \mathrm{CI}(87.4-94.0) & 85.9 \%, 95 \% \mathrm{CI}(81.7-90.1) \\ \geq 5 \% & 66.7 \%, 95 \% \mathrm{CI}(54.5-78.9) & 66.7 \%, 95 \% \mathrm{CI}(54.5-78.9)\end{array}$

A

B

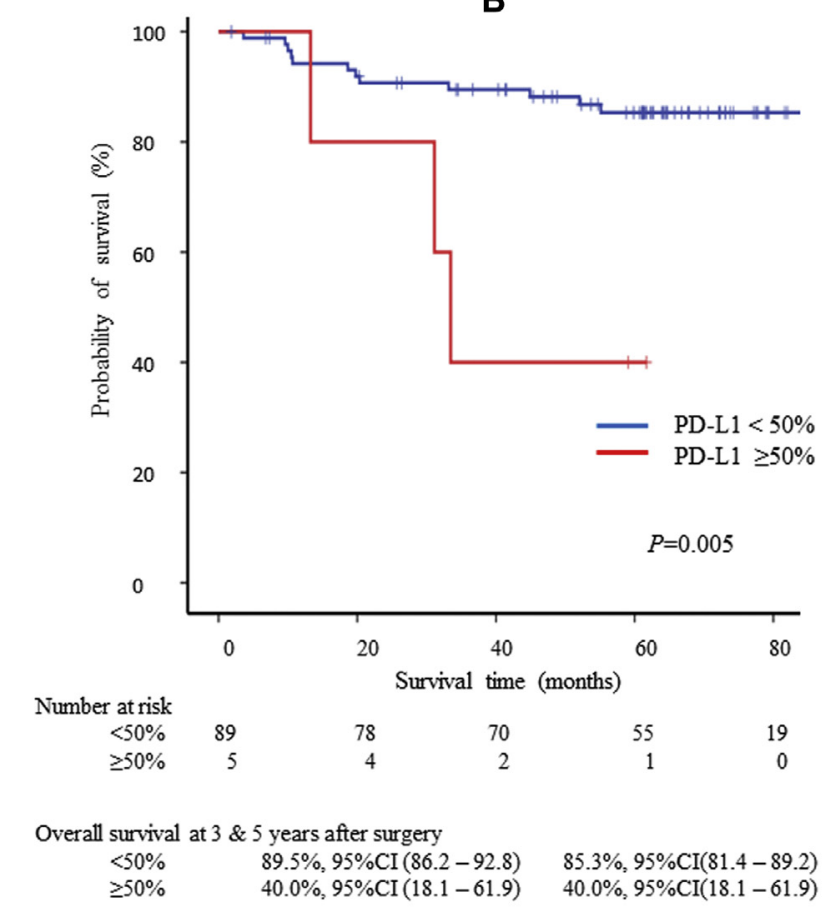

\section{C}

FIGURE 2. OS curves according to PD-L1 expression status classified by the percentage of tumor cells expressing PD-L1 at the cutoff value of $1 \%$ (A), $5 \%$ (B), or $50 \%$ (C). $C I$, Confidence interval; $P D-L 1$, programmed death-ligand 1 .

$88.3 \%$ versus $50.0 \%$ at the cutoff value of $50 \%(P=.022)$ (Figure 3,C), respectively. PD-L1 expression (cutoff value, $5 \%$ ) along with sex and p-stage were included in a multivariable analysis (model 1), and PD-L1 positivity was a marginal factor to predict a poor prognosis (HR, 3.099; 95\% CI, $0.956-9.261 ; P=.058$ ) (Table 2 ). In a multivariable analysis in which PD-L1 expression (cutoff value, 50\%) was included
(Model 2), the prognostic impact of PD-L1 positivity seemed less significant (HR, 4.372; 95\% CI, 0.804-13.771; $P=.088$ ) (Table 2).

Among patients with "reduced" HLA class I expression, PD-L1 expression status provided no prognostic impact: 5-year survival, $80.4 \%$ versus $75.0 \%$ at the cutoff value of $1 \% ; 80.9 \%$ versus $71.4 \%$ at the cutoff value of $5 \%$ 


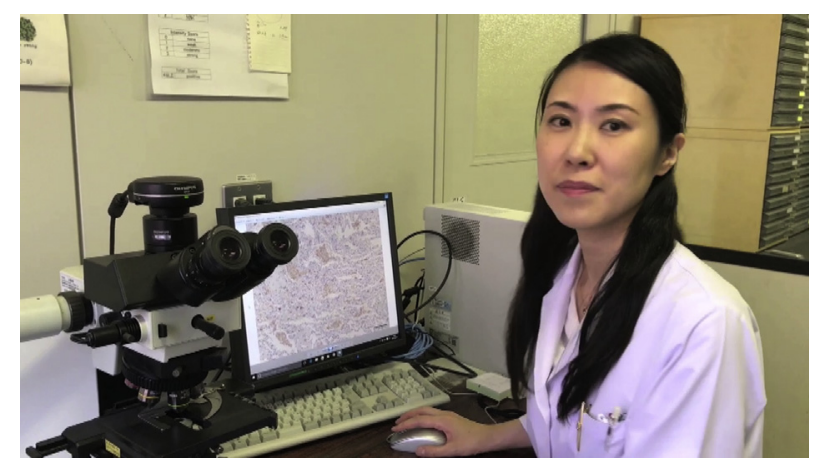

VIDEO 1. This retrospective study indicated that the prognostic impact of PD-L1 expression on tumor cells might be distinct according to HLA class I expression status in pathologic stage I lung adenocarcinoma. When HLA class I expression was reduced, PD-L1 expression status was not a significant prognostic factor. By contrast, when HLA class I expression was sufficient as represented by "normal," positivity of PD-L1 expression was associated with a poor prognosis. Video available at: http://www. jtcvsonline.org/article/S0022-5223(17)31190-X/fulltext.

(Figure $3, B) ; 81.4 \%$ versus $0.0 \%$ at the cutoff value of $50 \%$ (Figure 3, D). Analyses among patients who did not receive adjuvant chemotherapy provided similar results (Table E1).

\section{DISCUSSION}

In the present study, we first showed that positive PD-L1 expression status on tumor cells was a potential factor to predict a poor prognosis, which may depend on concurrent HLA class I expression status on tumor cells in lung adenocarcinoma. PD-L1 positivity was found to be correlated with a poor prognosis when concurrent HLA class I was adequately expressed on tumor cells, but PD-L1 expression status provided no prognostic impact when concurrent HLA class I expression was reduced.

The clinical implications of PD-L1 expression status in NSCLC have been reported in previous studies, ${ }^{11}$ in correlation with tumor characteristics including mutational burden, prognosis, and response to immune-checkpoint inhibitors, such as anti-PD-1 antibodies (ie, nivolumab ${ }^{6,7}$ and pembrolizumab $^{8}$ ) and anti-PD-L1 antibodies (ie, atezolizu$\mathrm{mab}^{9}$ and durvalumab ${ }^{10}$ ). In many studies conducted for advanced NSCLC, positive or stronger PD-L1 expression was correlated with favorable clinical benefits achieved with anti-PD-1/PD-L1 antibodies. ${ }^{7-9}$ As for the prognostic impact of PD-L1, however, many conflicting results have been reported, partly because of the vast heterogeneity of patient characteristics, including histologic subtypes and tumor stage, indicating the need for studies with homogenous patient populations. Accordingly, in the current study, we assessed the prognostic impact exclusively among patients with completely resected p-stage I lung adenocarcinoma. When we systematically searched for similar articles in PubMed as of December 31, 2016, using the terms "lung" and "adenocarcinoma" and "PDL1" and "survival OR prognosis" only in the English literature, 13 eligible articles were identified ${ }^{18-30}$ (Table 3). Ten of 23 searched articles were ineligible, because no prognostic impact of PD-L1 expression status was examined. Most studies ( 9 of 13 searched studies, along with the present study) indicated a significantly poor prognosis in positive PD-L1 patients, whereas 3 studies indicated a favorable prognosis in positive PD-L1 patients. ${ }^{18,25,27}$ Concerning clinicopathologic and molecular features, most studies showed that positive PD-L1 expression was associated with increased smoking history and poor differentiation, and the significant association between PD-L1 expression and poor differentiation also was documented in the current study. Five studies showed a positive association between the PD-L1 expression and the absence of epidermal growth factor receptor mutations, as a similar trend shown in the present study. In contrast, 1 study showed a positive association between the PD-L1 expression and the presence of epidermal growth factor receptor mutations. ${ }^{20}$ Overall, positive PD-L1 expression was associated with more aggressive tumor behavior such as poor differentiation in adenocarcinoma of the lung, but the prognostic impact may remain controversial in such a homogenous population. Therefore, the prognostic impact of PD-L1 expression may be influenced by other factors associated with cancer immunity, such as HLA class I.

Cancer immunity comprises a series of steps as follows: (1) release of neoantigens from tumor cells; (2) capture and processing of neoantigens by antigen presenting cells (APCs); (3) activation of cytotoxic T-cells (CTLs) through presentation of processed neoantigens by APCs; (4) recognition and binding to tumor cells by CTLs through interaction between T-cell receptor on CTLs and its cognate neoantigen on HLA class I molecules on T cells; and (5) killing of target $\mathrm{T}$ cells by CTLs. ${ }^{31-33}$ HLA class I molecules expressing on tumor cells play critical roles in the step of recognition and binding by CTLs, and tumor cells with reduced expression of HLA class I molecules may evade recognition by CTLs to survive. ${ }^{12-14}$ Accordingly, expression status of HLA class I molecules on tumor cells may influence prognosis, and several clinical studies showed that downregulation or low expression of HLA class I antigens was associated with a poor prognosis in a variety of malignant tumors, including NSCLC. ${ }^{17,34-36}$ PD-L1, expressing on tumor cells, also plays an important role in immune evasion at the final step by inhibiting activated CTLs. Accordingly, tumor cells with reduced HLA class I expression may evade immune attack regardless of PD-L1 expression on tumor cells, which may account for the lack of prognostic impact of PD-L1 status in tumors with reduced HLA class I expression found in the present study. Nevertheless, 

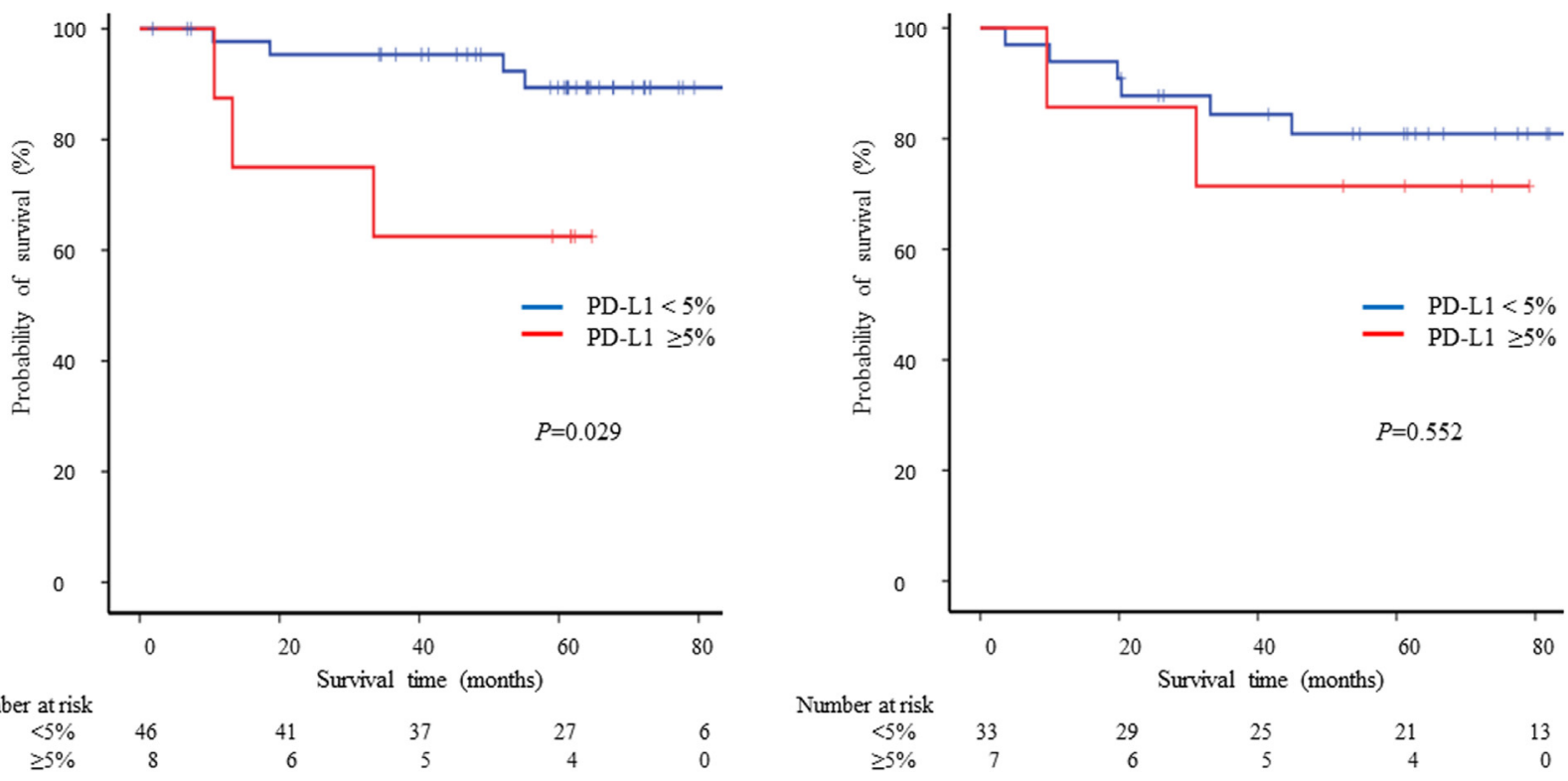
Overall survival at $3 \& 5$ years after surgery
$<5 \% \quad 95.3 \%, 95 \% \mathrm{CI}(92.1-98.5) \quad 89.4 \%, 95 \% \mathrm{CI}(84.3-94.5)$
$\geq 5 \% \quad 62.5 \%, 95 \% \mathrm{CI}(45.7-79.6) \quad 62.5 \%, 95 \% \mathrm{CI}(45.7-79.6)$

A

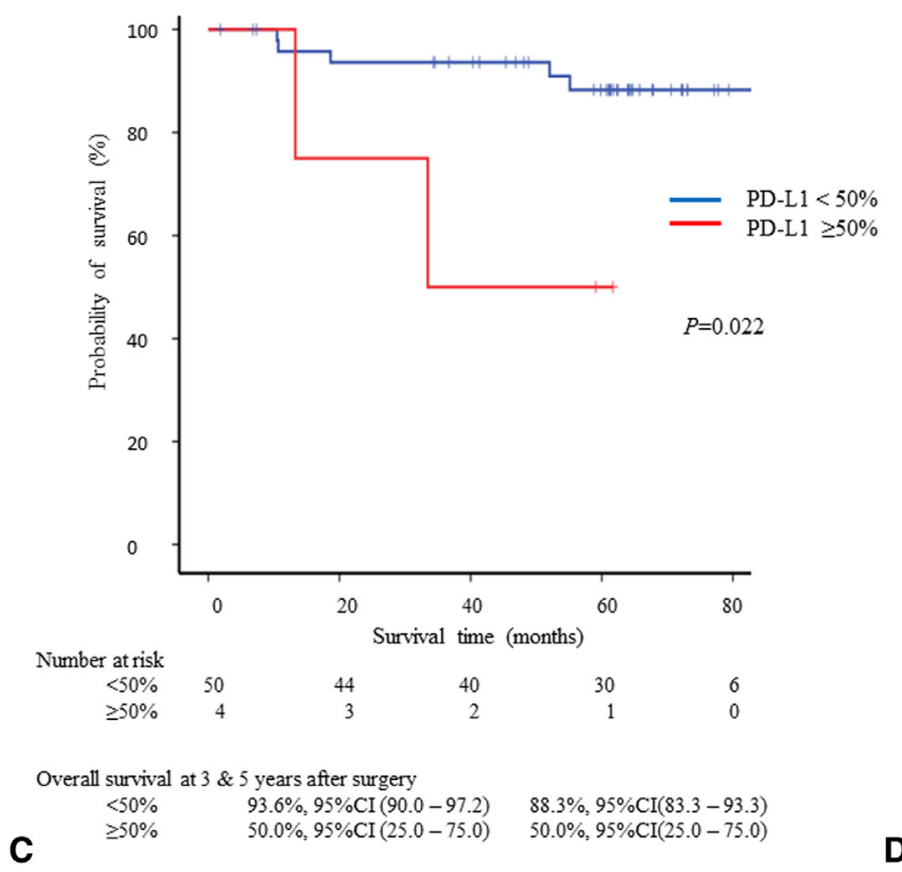

Overall survival at $3 \& 5$ years after surgery

$<5 \% \quad 84.4 \%, 95 \% \mathrm{CI}(78.0-90.8) \quad 80.9 \%, 95 \% \mathrm{CI}(73.8-88.0)$

B

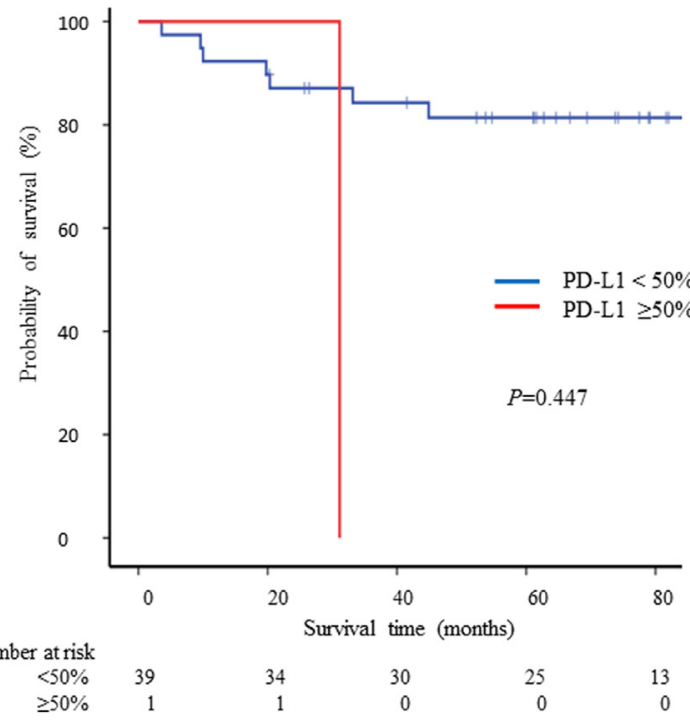

Overall survival at $3 \& 5$ years after surgery

$\begin{array}{lrr}<50 \% & 83.4 \%, 95 \% \mathrm{CI}(78.9-90.2) & 81.4 \%, 95 \% \mathrm{CI}(75.0-87.8) \\ \geq 50 \% & 0.0 \%, 95 \% \mathrm{CI}(0.0-0.0) & 0.0 \%, 95 \% \mathrm{CI}(0.0-0.0)\end{array}$

D

FIGURE 3. OS according to PD-L1 expression status after stratification by HLA class I expression status. HLA class I status was classified on the basis of the percentage of tumor cells expressing HLA class I molecules into "normal" $(\geq 80 \%)$ or "reduced" $(<80 \%)$. A, OS curves of PD-L1 5\% or greater and less than 5\% cases among "normal" HLA class I cases. B, OS curves of PD-L1 5\% or greater and less than 5\% cases among "reduced" HLA class I cases. C, OS curves of PD-L1 50\% or greater and less than 50\% cases among "normal" HLA class I cases. D, OS curves of PD-L1 50\% or greater and less than $50 \%$ cases among "reduced" HLA class I cases. $C I$, Confidence interval; PD- $L 1$, programmed death-ligand 1.

tumor cells with HLA class I expression can be recognized by CTLs and may evade immune attack by expressing PD-L1, which also may account for the result that PD-
L1 positivity was associated with a poor prognosis in tumors with normal HLA class I expression. In the present study, a multivariate analysis failed to show a significant 
TABLE 2. Univariable and Multivariable Cox model of prognostic factors for overall survival

\begin{tabular}{|c|c|c|c|c|c|c|c|c|c|c|c|c|}
\hline \multirow[b]{3}{*}{ Variables } & \multirow{2}{*}{\multicolumn{3}{|c|}{ Univariable analysis }} & \multicolumn{9}{|c|}{ Multivariable analysis (Model 1) } \\
\hline & & & & \multicolumn{3}{|c|}{ All patients } & \multicolumn{3}{|c|}{ HLA normal only } & \multicolumn{3}{|c|}{ HLA reduced only } \\
\hline & HR & $95 \% \mathrm{CI}$ & $\boldsymbol{P}$ & $\overline{\text { HR }}$ & $95 \%$ CI & $P$ & HR & $95 \% \mathrm{CI}$ & $P$ & $\overline{\text { HR }}$ & $95 \% \mathrm{CI}$ & $P$ \\
\hline Age (per 1-y increase) & 1.016 & $0.964-1.069$ & .558 & & & & & & & & & \\
\hline Sex, female (vs male) & 0.165 & $0.037-0.726$ & .017 & 0.214 & $0.048-0.968$ & .045 & 0.190 & $0.023-1.578$ & .124 & 0.189 & $0.022-1.637$ & .130 \\
\hline Smoker (vs never smoker) & 2.273 & $0.733-7.052$ & .155 & & & & & & & & & \\
\hline \multicolumn{13}{|l|}{ Comorbidities, present (vs absent) } \\
\hline Pulmonary & 0.665 & $0.188-2.357$ & .527 & & & & & & & & & \\
\hline Cardiovascular & 0.764 & $0.215-2.706$ & .676 & & & & & & & & & \\
\hline Others & 0.787 & $0.099-5.751$ & .756 & & & & & & & & & \\
\hline $\begin{array}{l}\text { Good differentiation (vs moderate } \\
\text { to poor) }\end{array}$ & 0.372 & $0.109-1.273$ & .115 & & & & & & & & & \\
\hline EGFR mutation (del 19 or L858R) & 0.674 & $0.215-2.118$ & .500 & & & & & & & & & \\
\hline $\begin{array}{l}\text { Normal HLA class I expression (vs } \\
\text { reduced HLA class I expression) }\end{array}$ & 0.636 & $0.231-1.755$ & .382 & & & & & & & & & \\
\hline \multicolumn{13}{|c|}{ PD-L1 expression, positive (vs negative) } \\
\hline$\geq 1 \%(\mathrm{vs}<1 \%)$ & 1.864 & $0.636-5.465$ & .257 & & & & & & & & & \\
\hline$\geq 5 \%(\mathrm{vs}<5 \%)$ & 2.811 & $1.060-8.227$ & .046 & 1.848 & $0.625-5.466$ & .267 & 3.099 & $0.956-9.261$ & .058 & 0.463 & $0.053-4.071$ & .488 \\
\hline$\geq 50 \%($ vs $<50 \%)$ & 5.136 & $1.342-18.279$ & .022 & & & & & & & & & \\
\hline $\begin{array}{l}\text { No. of nodes dissected, median } \\
\text { or greater (vs less than median) }\end{array}$ & 0.803 & $0.291-2.215$ & .672 & & & & & & & & & \\
\hline Pathologic stage IB (vs IA) & 3.101 & $1.123-8.565$ & .029 & 2.236 & $0.800-6.246$ & .125 & 1.822 & $0.398-8.340$ & .440 & 2.922 & $0.620-13.775$ & .175 \\
\hline $\begin{array}{l}\text { Adjuvant chemotherapy, performed } \\
\text { (vs not performed) }\end{array}$ & 0.532 & $0.070-4.048$ & .542 & & & & & & & & & \\
\hline
\end{tabular}

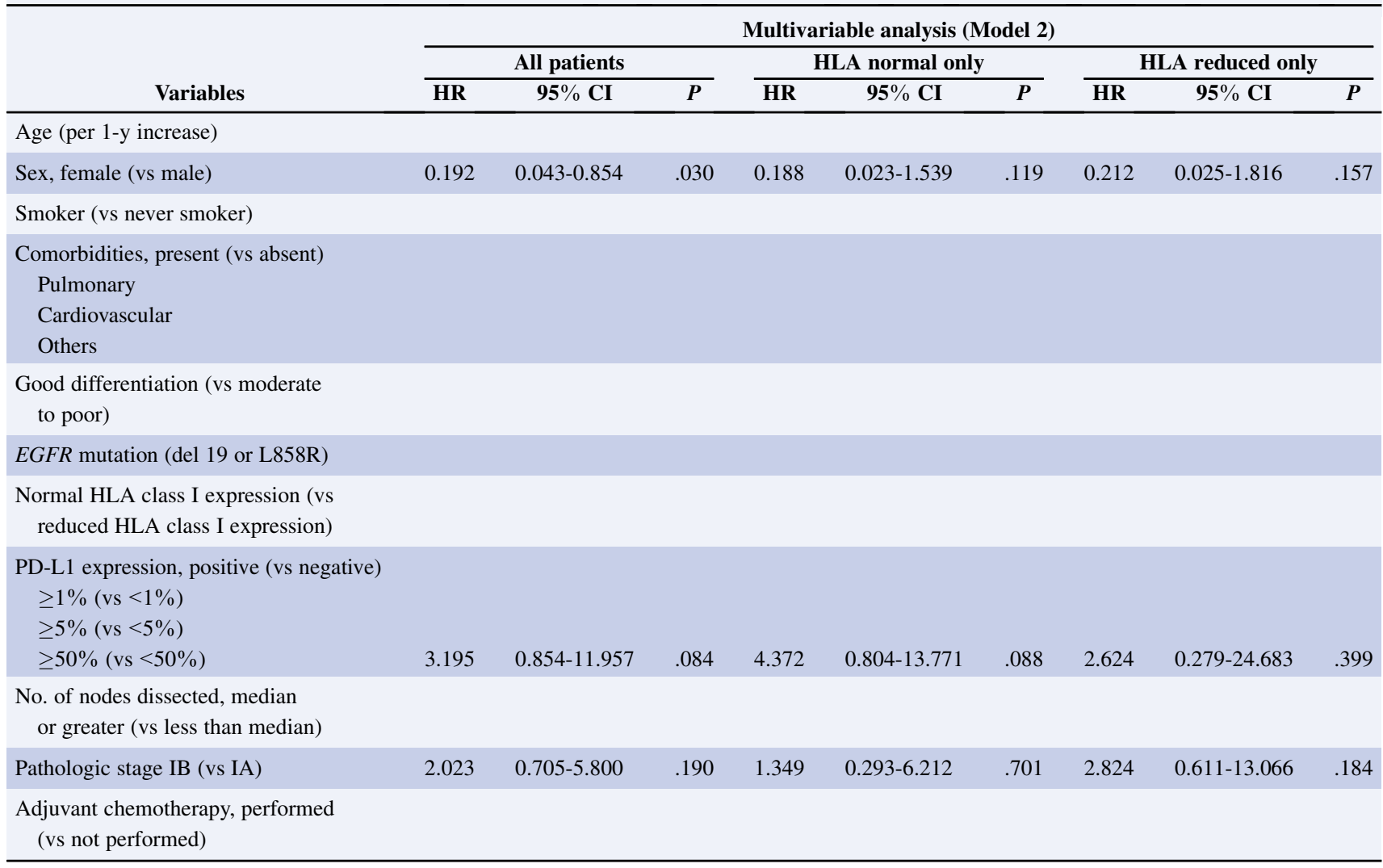

HLA, Human leukocyte antigen; $H R$, hazard ratio; $C I$, confidence interval; $E G F R$, epidermal growth factor receptor; PD-L1, programmed death-ligand 1 . 
TABLE 3. Summary of reported studies on programmed death-ligand 1 expression in adenocarcinoma of the lung

\begin{tabular}{|c|c|c|c|c|c|c|c|c|}
\hline $\begin{array}{l}\text { Author }(\mathbf{y}) \\
\text { [reference] }\end{array}$ & $\mathbf{N}$ & Stage (n) & $\begin{array}{l}\text { Distribution } \\
\text { of PD-L1 } \\
\text { expression }\end{array}$ & $\begin{array}{l}\text { Cutoff } \\
\text { for PD-L1 } \\
\text { positivity }\end{array}$ & $\begin{array}{c}\text { Antibody } \\
\text { used in IHC }\end{array}$ & $\begin{array}{c}\text { No. of } \\
\text { positive } \\
\text { PD-L1 } \\
\text { patients (\%) }\end{array}$ & $\begin{array}{c}\text { Prognosis } \\
\text { of positive } \\
\text { PD-L1 } \\
\text { patients }\end{array}$ & $\begin{array}{c}\text { Correlation } \\
\text { between PD-LI } \\
\text { positivity and } \\
\text { other factors }\end{array}$ \\
\hline $\begin{array}{r}\text { Yang CY } \\
2014^{18}\end{array}$ & 163 & I (163) & Membrane & $\begin{array}{r}\geq 5 \% \text {, any } \\
\text { intensity }\end{array}$ & $\begin{array}{l}\text { Proteintech } \\
\text { (Proteintech, } \\
\text { Rosemont, Ill) }\end{array}$ & $65(40 \%)$ & $\begin{array}{l}\text { Better RFS } \\
\quad(P=.027) \\
\text { No OS difference } \\
\quad(P=.933)\end{array}$ & $\begin{array}{l}\text { Higher-grade } \\
\text { differentiation } \\
\text { Vascular invasion; } \\
\text { not correlated } \\
\text { with EGFR }\end{array}$ \\
\hline $\begin{array}{r}\text { Zhang Y } \\
2014^{19}\end{array}$ & 143 & I (66) II-III (77) & $\begin{array}{l}\text { Membrane and } \\
\text { cytoplasm }\end{array}$ & $\begin{array}{l}\text { Intensity and } \\
\text { percentage } \\
\text { (score) }\end{array}$ & $\begin{array}{l}\text { SAB2900365 } \\
\text { (Sigma-Aldrich, } \\
\text { St Louis, Mo) }\end{array}$ & $70(49 \%)$ & $\begin{array}{l}\text { Poor RFS }(P<.001) \\
\text { Poor OS }(P=.002)\end{array}$ & $\begin{array}{l}\text { Higher p-stage } \\
\text { (T-/N-factor) } \\
\text { Solid-predominant } \\
\text { type } \\
\text { Not correlated with } \\
\text { EGFR }\end{array}$ \\
\hline $\begin{array}{l}\text { Song Z } \\
2016^{20}\end{array}$ & 385 & $\begin{array}{l}\text { I (121) II (79), } \\
\text { III (185) }\end{array}$ & Membrane & $\begin{array}{l}\geq 5 \% \text {, any } \\
\text { intensity }\end{array}$ & Proteintech & $186(48 \%)$ & $\begin{array}{l}\text { Poor DFS }(38.0 \mathrm{mo} \\
\text { vs } 50.4 \mathrm{mo} \\
P=.014) \\
\text { Poor OS (trend, } \\
52.9 \mathrm{mo} \text { vs } \\
68.2 \mathrm{mo} \\
P=.069)\end{array}$ & $\begin{array}{l}\text { Coexisting } \\
\text { mutations } \\
\text { including EGFR- } \\
\text { mutations }\end{array}$ \\
\hline $\begin{array}{l}\text { Ji M } \\
\qquad 2016^{21}\end{array}$ & 100 & $\begin{array}{c}\text { I (42) II (27), } \\
\text { III (31) }\end{array}$ & $\begin{array}{l}\text { Membrane and } \\
\text { cytoplasm }\end{array}$ & $\begin{array}{l}\text { Intensity and } \\
\text { percentage } \\
\text { (score) }\end{array}$ & $\begin{array}{l}\text { Abcam (Abcam, } \\
\text { Cambridge, UK) }\end{array}$ & $40(40 \%)$ & $\begin{array}{l}\text { Poor } 3-y \text { OS } \\
\quad(62.5 \% \text { vs } \\
83.3 \% \\
P=.034)\end{array}$ & EGFR wild-type \\
\hline $\begin{array}{l}\text { Cha YJ } \\
\qquad 2016^{22}\end{array}$ & 323 & $\begin{array}{l}\text { I (177) II (58) } \\
\text { III (81), } \\
\text { IV (7) }\end{array}$ & Membrane & & $\begin{array}{l}\text { SP142 (Spring } \\
\text { Bioscience, } \\
\text { Pleasanton, } \\
\text { Calif) }\end{array}$ & $60(19 \%)$ & $\begin{array}{l}\text { Poor RFS }(P<.001) \\
\text { Poor OS }(P<.001)\end{array}$ & $\begin{array}{l}\text { Solid-predominant } \\
\text { type } \\
\text { Higher stage } \\
\text { EGFR wild-type }\end{array}$ \\
\hline $\begin{array}{c}\text { Shimoji M } \\
2016^{23}\end{array}$ & 165 & I (113) II-IV (52) & Membrane & $\begin{array}{l}\text { Intensity and } \\
\text { percentage } \\
\text { (score) }\end{array}$ & $\begin{array}{l}\text { E1L3N (Cell } \\
\text { Signaling, } \\
\text { Danvers, Mass) }\end{array}$ & $37(22 \%)$ & $\begin{array}{l}\text { Poor OS } \\
\qquad(P=.0051)\end{array}$ & $\begin{array}{l}\text { Smoking solid- } \\
\text { predominant } \\
\text { subtype }\end{array}$ \\
\hline $\begin{array}{c}\text { Inamura K } \\
2016^{24}\end{array}$ & 268 & & Membrane & $\begin{array}{r}\geq 5 \% \text {, any } \\
\text { intensity }\end{array}$ & E1L3N & $43(16 \%)$ & $\begin{array}{l}\text { Poor OS } \\
\quad(P=.0014) \\
\text { Poor lung cancer- } \\
\quad \text { specific survival } \\
\quad(P=.019)\end{array}$ & $\begin{array}{l}\text { Smoking (trend) } \\
\text { Less differentiation } \\
\text { (moderate to } \\
\text { poorly) } \\
\text { EGFR wild-type }\end{array}$ \\
\hline $\begin{array}{r}\text { Huang JJ } \\
2016^{25}\end{array}$ & 112 & $\begin{array}{l}\text { I (94) II (4) } \\
\text { III (14) }\end{array}$ & $\begin{array}{l}\text { Membrane and } \\
\text { cytoplasm }\end{array}$ & $\begin{array}{l}\text { Intensity and } \\
\text { percentage } \\
\text { (score) }\end{array}$ & Proteintech & $99(88 \%)$ & $\begin{array}{l}\text { Better OS } \\
\qquad(P=.023)\end{array}$ & $\begin{array}{l}\text { Acinar- } \\
\text { predominant } \\
\text { Less papillary- } \\
\text { predominant not } \\
\text { correlated with } \\
\text { EGFR }\end{array}$ \\
\hline $\begin{array}{r}\text { Takada K } \\
2016^{26}\end{array}$ & 417 & $\begin{array}{c}\text { I (305) II (63) } \\
\text { III (49) }\end{array}$ & Membrane & $\begin{array}{l}\geq 5 \% \text { or } \\
\quad \geq 1 \% \text {, any } \\
\quad \text { intensity }\end{array}$ & SP142 & $\begin{array}{r}144(35 \%, \geq 1 \%) \\
85(20 \%, \geq 5 \%)\end{array}$ & $\begin{array}{l}\text { Poor OS } \\
\qquad(P<.001 \geq 1 \% ; \\
\quad .0010 \geq 5 \%) \\
\text { Poor DFS } \\
\quad(P<.0001 / 1 \% ; \\
0.0049 / 5 \%)\end{array}$ & $\begin{array}{l}\text { Smoking } \\
\text { Advanced p-stage } \\
\text { micropapillary, } \\
\text { solid- } \\
\text { predominant } \\
\text { pleural, vessel } \\
\text { invasion } \\
\text { EGFR wild-type }\end{array}$ \\
\hline $\begin{array}{c}\text { Huynh TG } \\
2016^{27}\end{array}$ & 261 & $\begin{array}{l}\text { I (201) II (34) } \\
\text { III (22), IV (4) }\end{array}$ & Membrane & $\begin{array}{c}\geq 1 \%, 5 \% \text {, or } \\
\quad 50 \% \text {, any } \\
\text { intensity }\end{array}$ & E1L3N & $\begin{aligned} 129(49 \% & \geq 1 \%) \\
95(36 \% & \geq 5 \%) \\
62(24 \% & \geq 50 \%)\end{aligned}$ & $\begin{array}{l}\text { Poor } 5 \text {-y PFS } \\
\quad(63 \% \text { vs } 79 \%, \\
P<.001 / 1 \% \\
66 \% \text { vs } 75 \%,\end{array}$ & $\begin{array}{l}\text { Smoking; solid- } \\
\text { predominant } \\
\text { higher nuclear } \\
\text { gradelymphatic, }\end{array}$ \\
\hline
\end{tabular}




\begin{tabular}{|c|c|c|c|c|c|c|c|c|}
\hline $\begin{array}{l}\text { Author (y) } \\
\text { [reference] }\end{array}$ & $\mathbf{N}$ & Stage (n) & $\begin{array}{c}\text { Distribution } \\
\text { of PD-L1 } \\
\text { expression }\end{array}$ & $\begin{array}{c}\text { Cutoff } \\
\text { for PD-L1 } \\
\text { positivity }\end{array}$ & $\begin{array}{c}\text { Antibody } \\
\text { used in IHC }\end{array}$ & $\begin{array}{c}\text { No. of } \\
\text { positive } \\
\text { PD-L1 } \\
\text { patients (\%) }\end{array}$ & $\begin{array}{c}\text { Prognosis } \\
\text { of positive } \\
\text { PD-L1 } \\
\text { patients }\end{array}$ & $\begin{array}{c}\text { Correlation } \\
\text { between PD-LI } \\
\text { positivity and } \\
\text { other factors }\end{array}$ \\
\hline & & & & & & & $\begin{array}{c}P=.007 / 5 \% \\
66 \% \text { vs } 73 \%, \\
P=.032 / 50 \%) \\
\text { Poor } 5 \text {-y OS }(70 \% \\
\text { vs } 89 \% \\
P=.002 / 1 \% \\
72 \% \text { vs } 85 \%, \\
P=.011 / 5 \% \\
79 \% \text { vs } 81 \%, \\
P=.118 / 50 \%)\end{array}$ & $\begin{array}{l}\text { venous invasion } \\
\text { EGFR wild-type }\end{array}$ \\
\hline $\begin{array}{l}\text { Ohue T } \\
2016^{28}\end{array}$ & 120 & I-IIIA & $\begin{array}{c}\text { Membrane and } \\
\text { cytoplasm }\end{array}$ & $\begin{array}{l}\text { Intensity and } \\
\text { percentage } \\
\text { (score) }\end{array}$ & $\begin{array}{l}\text { ProSci (ProSci, } \\
\text { Poway, Calif) }\end{array}$ & $53(44 \%)$ & $\begin{array}{l}\text { Better OS (trend, } \\
\quad P=.09)\end{array}$ & \\
\hline $\begin{array}{l}\text { Uruga } \mathrm{H} \\
2016^{29}\end{array}$ & 109 & II-III & Membrane & $\begin{array}{c}\geq 1 \%, 5 \% \text { or } \\
50 \%, \text { any } \\
\text { intensity }\end{array}$ & E1L3N & $\begin{array}{l}56(51 \% \geq 1 \%) \\
43(39 \% \geq 5 \%) \\
19(17 \% \geq 50 \%)\end{array}$ & $\begin{array}{l}\text { No } 5 \text {-y PFS } \\
\quad \begin{array}{l}(57 \% \text { vs } 45 \%, \\
P=.283 / 1 \% ; \\
55 \% \text { vs } 48 \%, \\
P=.373 / 5 \% \\
55 \% \text { vs } 50 \% \\
P=.888 / 50 \%)\end{array}\end{array}$ & $\begin{array}{l}\text { Solid-dominant } \\
\text { presence of } \\
\text { tumor island, } \\
\text { necrosis, } \\
\text { vascular } \\
\text { invasion; higher } \\
\text { nuclear grade } \\
\text { nodal } \\
\text { involvement }\end{array}$ \\
\hline $\begin{array}{l}\text { Mori S } \\
2017^{30}\end{array}$ & 296 & I-III & & $\begin{array}{l}\text { Intensity and } \\
\text { percentage } \\
\text { (score) }\end{array}$ & EPR1611 (Abcam) & $107(36 \%)$ & $\begin{array}{l}\text { Poor DFS }(69 \% \\
\quad \text { vs } 81 \% \text { at } 3 \text { y; } \\
\quad P=.021) \\
\text { Poor OS }(85 \% \\
\quad \text { vs } 94 \% \text { at } 3 y \text {; } \\
\quad P=.005)\end{array}$ & $\begin{array}{l}\text { Smoking; poor } \\
\text { differentiation } \\
\text { Not correlated } \\
\text { with EGFR }\end{array}$ \\
\hline $\begin{array}{r}\text { Current } \\
\text { study }\end{array}$ & 94 & I & Membrane & $\begin{array}{c}\geq 1 \%, 5 \%, \text { or } \\
50 \% \text {, any } \\
\text { intensity }\end{array}$ & E1L3N & $\begin{array}{l}21(22 \% \geq 1 \%) \\
15(16 \% \geq 5 \%) \\
5(5 \% \geq 50 \%)\end{array}$ & $\begin{array}{c}\text { Poor } 5 \text {-y OS (trend, } \\
76 \% \text { vs } 85 \% \\
P=.249 / 1 \% \\
67 \% \text { vs } 86 \% \\
P=.048 / 5 \% \\
40 \% \text { vs } 85 \% \\
P=.0049 / 50 \%)\end{array}$ & $\begin{array}{l}\text { Less differentiation } \\
\text { EGFR wild-type } \\
\text { (trend) }\end{array}$ \\
\hline
\end{tabular}

$P D-L 1$, Programmed death-ligand 1; $I H C$, immunohistochemistry; $R F S$, recurrence-free survival; $O S$, overall survival; $E G F R$, epidermal growth factor receptor; $D F S$, diseasefree survival; $P F S$, progression-free survival.

prognostic value of PD-L1 expression in tumor with normal HLA class I expression $(P=.058)$, most likely because of a relatively small number of patients.

\section{Study Limitations}

Although this study suggested that the prognostic values of PD-L1 expression were distinct according to HLA class I expression, this study had several limitations due to a variety of weaknesses other than its small number of patients. First, this study was a retrospective single-institutional study. Second, a certain percentage of patients were lost to follow-up in this study (approximately one fourth of patients at 5 years after surgery). In addition, the impact of PD-L1 status on postoperative recurrence and postoperative death is important, which was not examined in this study because adequate recurrence data were not available. Finally, the number of events for OS analysis was relatively small (15 deaths in the entire study cohort). To draw more conclusive results, we are currently conducting a larger-scale retrospective study. In addition, the prognostic impact of PD-L1 may be influenced not only by HLA class I but also by other factors associated with immune response (eg, major histocompatibility complex class II molecules and PD-1) and other pathologic factors (eg, specific subtypes of adenocarcinoma), and these factors should be included and analyzed in future studies. 


\section{CONCLUSIONS}

The prognostic impact of PD-L1 expression was distinct according to HLA class I expression status in resectable adenocarcinoma of the lung. PD-L1 positivity on tumor cells was associated with a poor prognosis when HLA class I expression was normal, but was not associated with prognosis when HLA class I expression was reduced.

\section{Conflict of Interest Statement}

Authors have nothing to disclose with regard to commercial support.

The authors thank Miyoko Takeshita for technical assistance.

\section{References}

1. Siegel RL, Miller KD, Jemal A. Cancer statistics, 2015. CA Cancer J Clin. 2015; 65:5-29.

2. Rosen JE, Salazar MC, Wang Z, Yu JB, Decker RH, Kim AW, et al. Lobectomy versus stereotactic body radiotherapy in healthy patients with stage I lung cancer. J Thorac Cardiovasc Surg. 2016;152:44-54.

3. Tsao AS, Scagliotti GV, Bunn PA Jr, Carbone DP, Warren GW, Bai C, et al. Scientific advances in lung cancer 2015. J Thorac Oncol. 2016;5:613-38.

4. Tanaka F, Yoneda K. Adjuvant therapy following surgery in non-small cell lung cancer (NSCLC). Surg Today. 2016;46:25-37.

5. Paradoll DM. The blockade of immune checkpoints in cancer immunotherapy. Nat Rev Cancer. 2012;12:252-64.

6. Brahmer J, Reckamp KL, Baas P, Crinò L, Eberhardt WE, Poddubskaya E, et al Nivolumab versus docetaxel in advanced squamous non-small-cell lung cancer. N Engl J Med. 2015;373:123-35.

7. Borghaei H, Paz-Ares L, Horn L, Spigel DR, Steins M, Ready NE, et al. Nivolumab versus Docetaxel in advanced nonsquamous non-small-cell lung cancer. $N$ Engl J Med. 2015;373:1627-39.

8. Herbst RS, Baas P, Kim DW, Felip E, Pérez-Gracia JL, Han JY, et al. Pembrolizumab versus docetaxel for previously treated PD-L1-positive, advanced nonsmall-cell lung cancer (KEYNOTE-010): a randomized controlled trial. Lancet. 2016;387:1540-50

9. Fehrenbacher L, Spira A, Ballinger M, Kowanetz M, Vansteenkiste J, Mazieres J, et al. Atezolizumab versus doctaxel for patients with previously treated nonsmall-cell lung cancer (POPLAR): a multicenter, open-label, phase 2 randomised controlled trial. Lancet. 2016;387:1837-46.

10. Reck M, Rodríguez-Abreu D, Robinson AG, Hui R, Csőszi T, Fülöp A, et al Pembrolizumab versus chemotherapy for PD-L1-positive non-small-cell lung cancer. N Engl J Med. 2016;375:1823-33.

11. Yu H, Boyle TA, Zhou C, Rimm DL, Hirsch FR. PD-L1 expression in lung cancer. J Thorac Oncol. 2016;11:964-75.

12. Mami-Chouaib F, Echchakir H, Dorothée G, Vergnon I, Chouaib S. Antitumor cytotoxic T-lymphocyte response in human lung carcinoma: identification of a tumor-associated antigen. Immunol Rev. 2002;188:114-21.

13. Chen L, Flies DB. Molecular mechanisms of $\mathrm{T}$ cell co-stimulation and co-inhibition. Nat Rev Immunol. 2013;13:227-42.

14. Sznol M, Chen L. Antagonist antibodies to PD-1 and B7-H1 (PD-L1) in the treatment of advanced human cancer. Clin Cancer Res. 2013;19:1021-34.

15. Sabbatino F, Villani V, Yearley JH, Deshpande V, Cai L, Konstantinidis IT, et al. PD-L1 and HLA class I antigen expression and clinical course of the disease in intrahepatic cholangiocarcinoma. Clin Cancer Res. 2016;22:470-8.

16. Umemoto Y, Okano S, Matsumoto Y, Nakagawara H, Matono R, Yoshiya S, et al. Prognostic impact of programmed cell death 1 ligand 1 expression in human leukocyte antigen class I-positive hepatocellular carcinoma after curative hepatectomy. J Gastroenterol. 2015;50:65-75.

17. Hanagiri T, Shigematsu Y, Shinohara S, Takenaka M, Oka S, Chikaishi Y, et al. Clinical significance of expression of cancer/testis antigen and down-regulation of class-I in patients with stage I non-small cell lung cancer. Anticancer Res. 2013;33:2123-8.
18. Yang CY, Lin MW, Chang YL, Wu CT, Yang PC. Programmed cell death-ligand 1 expression in surgically resected stage I pulmonary adenocarcinoma and its correlation with driver mutations and clinical outcomes. Eur J Cancer. 2014; 50:1361-9.

19. Zhang Y, Wang L, Li Y, Pan Y, Wang R, Hu H, et al. Protein expression of programmed death 1 ligand 1 and ligand 2 independently predict poor prognosis in surgically resected lung adenocarcinoma. Onco Targets Ther. 2014; 7:567-73.

20. Song Z, Yu X, Cheng G, Zhang Y. Programmed death-ligand 1 expression associated with molecular characteristics in surgically resected lung adenocarcinoma. J Transl Med. 2016;14:188.

21. Ji M, Liu Y, Li Q, Li X, Ning Z, Zhao W, et al. PD-1/PD-L1 expression in nonsmall-cell lung cancer and its correlation with EGFR/KRAS mutations. Cancer Biol Ther. 2016;17:407-13.

22. Cha YJ, Kim HR, Lee CY, Cho BC, Shim HS. Clinicopathological and prognostic significance of programmed cell death ligand-1 expression in lung adenocarcinoma and its relationship with p53 status. Lung Cancer. 2016;97: 73-80.

23. Shimoji M, Shimizu S, Sato K, Suda K, Kobayashi Y, Tomizawa K, et al. Clinical and pathologic features of lung cancer expressing programmed cell death ligand 1 (PD-L1). Lung Cancer. 2016;98:69-75.

24. Inamura K, Yokouchi Y, Sakakibara R, Kobayashi M, Subat S, Ninomiya H, et al. Relationship of tumor PD-L1 expression with EGFR wild-type status and poor prognosis in lung adenocarcinoma. Jpn J Clin Oncol. 2016;46: 935-41.

25. Hung JJ, Huang SF, Shen YY, Wu YC, Chou TY, Hsu WH. Prognostic significance of programmed cell death-ligand 1 expression in patients with resected lung adenocarcinoma. Ann Thorac Surg. October12, 2016 [Epub ahead of print].

26. Takada K, Okamoto T, Shoji F, Shimokawa M, Akamine T, Takamori S, et al. Clinical significance of PD-L1 protein expression in surgically resected primary lung adenocarcinoma. J Thorac Oncol. 2016;11:1879-90.

27. Huynh TG, Morales-Oyarvide V, Campo MJ, Gainor JF, Bozkurtlar E, Uruga H, et al. Programmed cell death ligand 1 expression in resected lung adenocarcinomas: association with immune microenvironment. J Thorac Oncol. 2016;11: 1869-78.

28. Ohue Y, Kurose K, Nozawa R, Isobe M, Nishio Y, Tanaka T, et al. Survival of lung adenocarcinoma patients predicted from expression of PD-L1, galectin-9, and XAGE1 (GAGED2a) on tumor cells and tumor-infiltrating T cells. Cancer Immunol Res. 2016;4:1049-60.

29. Uruga H, Bozkurtlar E, Huynh TG, Muzikansky A, Goto Y, GomezCaraballo M, et al. Programmed cell death ligand (PD-L1) expression in stage II and III lung adenocarcinomas and nodal metastases. J Thorac Oncol. 2016;12:458-66.

30. Mori S, Motoi N, Ninomiya H, Matsuura Y, Nakao M, Mun M, et al. High expression of programmed cell death 1 ligand 1 in lung adenocarcinoma is a poor prognostic factor particularly in smokers and wild-type epidermal growth-factor receptor cases. Pathol Int. 2017;67:37-44.

31. Chen DS, Mellman I. Oncology meets immunology: the cancer-immunity cycle Immunity. 2013;39:1-10

32. Alexandrov LB, Nik-Zainal S, Wedge DC, Aparicio SA, Behjati S, Biankin AV, et al. Signatures of mutational processes in human cancer. Nature. 2013;500: 415-21.

33. Rizvi NA, Hellmann MD, Snyder A, Kvistborg P, Makarov V, Havel JJ, et al. Mutational landscape determines sensitivity to PD-1 blockade in non-small cell lung cancer. Science. 2015;348:124-8.

34. Marincola FM, Jaffee EM, Hicklin DJ, Ferrone S. Escape of human solid tumors from T-cell recognition: molecular mechanisms and functional significance. $A d v$ Immunol. 2000;74:181-273.

35. Chang CC, Campoli M, Ferrone S. HLA class I defects in malignant lesions: what have we learned? Keio J Med. 2003;52:220-9.

36. Powell AG, Horgan PG, Edwards J. The bodies fight against cancer: is human leucocyte antigen (HLA) class 1 the key? J Cancer Res Clin Oncol. 2012;138: $723-8$.

Key Words: PD-L1, HLA, lung, adenocarcinoma, prognosis 
TABLE E1. Univariable and multivariable Cox model of prognostic factors for overall survival

\begin{tabular}{|c|c|c|c|c|c|c|c|c|c|c|c|c|}
\hline \multirow[b]{3}{*}{ Variables } & \multirow{2}{*}{\multicolumn{3}{|c|}{ Univariable analysis }} & \multicolumn{9}{|c|}{ Multivariable analysis (Model 1) } \\
\hline & & & & \multicolumn{3}{|c|}{ All patients } & \multicolumn{3}{|c|}{ HLA normal only } & \multicolumn{3}{|c|}{ HLA reduced only } \\
\hline & HR & $95 \% \mathrm{CI}$ & $P$ & HR & $95 \% \mathrm{CI}$ & $P$ & HR & $95 \% \mathrm{CI}$ & $P$ & HR & $95 \% \mathrm{CI}$ & $P$ \\
\hline Age (per 1-y increase) & 1.011 & $0.960-1.065$ & .676 & & & & & & & & & \\
\hline Sex (female) & 0.088 & $0.011-0.671$ & .019 & 0.128 & $0.016-1.022$ & .052 & 0.265 & $0.030-2.344$ & .232 & 0.249 & $0.027-2.267$ & .217 \\
\hline Smoker (vs never smoker) & 2.977 & $0.830-10.677$ & .194 & & & & & & & & & \\
\hline \multicolumn{13}{|l|}{ Comorbidities } \\
\hline Pulmonary & 0.747 & $0.208-2.678$ & .654 & & & & & & & & & \\
\hline Cardiovascular & 0.930 & $0.259-3.334$ & .911 & & & & & & & & & \\
\hline Others & 0.711 & $0.093-5.440$ & .743 & & & & & & & & & \\
\hline $\begin{array}{l}\text { Good differentiation } \\
\text { (vs moderate to poor) }\end{array}$ & 0.391 & $0.175-1.127$ & .117 & & & & & & & & & \\
\hline EGFR mutation (del 19 or L858R) & 0.687 & $0.215-2.191$ & .526 & & & & & & & & & \\
\hline Normal HLA class I expression & 0.790 & $0.277-2.253$ & .659 & & & & & & & & & \\
\hline \multicolumn{13}{|l|}{ PD-L1 expression } \\
\hline$\geq 1 \%(\mathrm{vs}<1 \%)$ & 2.435 & $0.813-7.293$ & .112 & & & & & & & & & \\
\hline$\geq 5 \%(\mathrm{vs}<5 \%)$ & 3.316 & $1.110-9.904$ & .032 & 1.889 & $0.617-5.780$ & .265 & 3.541 & $0.976-12.441$ & .054 & 1.228 & $0.223-6.747$ & .813 \\
\hline$\geq 50 \%($ vs $<50 \%)$ & 6.789 & $1.867-24.696$ & .014 & & & & & & & & & \\
\hline $\begin{array}{l}\text { No. of nodes dissected, median } \\
\text { or greater (vs less than median) }\end{array}$ & 0.828 & $0.290-2.362$ & .724 & & & & & & & & & \\
\hline Pathologic stage IB (vs IA) & 4.782 & $1.669-13.704$ & .004 & 3.162 & $1.075-9.303$ & .036 & 2.851 & $0.640-12.694$ & .169 & 3.201 & $0.665-15.407$ & .147 \\
\hline
\end{tabular}

\begin{tabular}{|c|c|c|c|c|c|c|c|c|c|}
\hline \multirow[b]{3}{*}{ Variables } & \multicolumn{9}{|c|}{ Multivariable analysis (Model 2) } \\
\hline & \multicolumn{3}{|c|}{ All patients } & \multicolumn{3}{|c|}{ HLA normal only } & \multicolumn{3}{|c|}{ HLA reduced only } \\
\hline & HR & $\mathbf{9 5} \%$ CI & $\boldsymbol{P}$ & HR & $95 \%$ CI & $P$ & HR & $95 \%$ CI & $P$ \\
\hline \multicolumn{10}{|l|}{ Age (per 1-y increase) } \\
\hline Sex (female) & 0.124 & $0.016-0.985$ & .048 & 0.238 & $0.027-2.073$ & .194 & 0.252 & $0.028-2.245$ & .217 \\
\hline \multicolumn{10}{|l|}{ Smoker (vs never smoker) } \\
\hline \multicolumn{10}{|l|}{$\begin{array}{l}\text { Comorbidities } \\
\text { Pulmonary } \\
\text { Cardiovascular } \\
\text { Others }\end{array}$} \\
\hline \multicolumn{10}{|l|}{$\begin{array}{l}\text { Good differentiation } \\
\text { (vs moderate to poor) }\end{array}$} \\
\hline \multicolumn{10}{|c|}{ EGFR mutation (del 19 or L858R) } \\
\hline \multicolumn{10}{|c|}{ Reduced HLA class I expression } \\
\hline \multicolumn{10}{|l|}{$\begin{array}{l}\text { PD-L1 expression } \\
\qquad 1 \%(\text { vs }<1 \%) \\
\geq 5 \%(\text { vs }<5 \%)\end{array}$} \\
\hline \multicolumn{10}{|c|}{$\begin{array}{l}\text { No. of nodes dissected, median } \\
\text { or greater (vs less than median) }\end{array}$} \\
\hline Pathologic stage IB (vs IA) & 2.849 & $0.922-8.807$ & .069 & 2.317 & $0.490-10.964$ & 289 & 2.859 & $0.547-14.950$ & .213 \\
\hline
\end{tabular}

$H L A$, Human leukocyte antigen; $H R$, hazard ratio; $C I$, confidence interval; $E G F R$, epidermal growth factor receptor; $P D-L 1$, programmed death-ligand 1 . 